\title{
Survey of Public Attitudes to Price- Fixing and Cartel Enforcement in Britain
}

\author{
by \\ Andreas Stephan \\ ESRC Centre for Competition Policy \& Norwich Law School, \\ University of East Anglia
}

\section{CCP Working Paper 07-12}

\begin{abstract}
The paper reports on results from a public survey on attitudes to collusion and cartel enforcement in Britain. Respondents demonstrate an understanding that price-fixing is harmful and should be punished. While there is strong support for high corporate fines and naming and shaming, only 1 in 10 Britons think individuals responsible should be imprisoned. Weak perceptions of the severity of price-fixing are confirmed by only 6 in 10 people considering such practices to be dishonest. Sex and age strongly influence attitudes. Education and newspaper readership have less of an effect, indicating poor information dissemination. Only 20\% would report their employer's involvement in price-fixing without guarantees of anonymity and/or a reward; $14 \%$ would not report at all for fear of consequences. Public opinion is divided as to whether leniency programmes are justifiable. Respondents consider public enforcement to be more important than compensating parties injured by cartels.
\end{abstract}

May 2007

JEL Classification Codes: K21; K42; L13; L41

Keywords: Cartels; Public Survey; Enforcement; UK Cartel Offence; Leniency; Private Enforcement; Competition Law

\section{Acknowledgements:}

My thanks to Graham Loomes, Morten Hviid, Catherine Waddams, and the members of the ESRC Centre for Competition Policy. The support of the Economic and Social Research Council (UK) and the Arts and Humanities Research Council (UK) are also gratefully acknowledged.

\section{Contact details:}

Andreas Stephan, ESRC Centre for Competition Policy, University of East Anglia, Norwich, NR4 7TJ, UK.

a.stephan@uea.ac.uk 


\section{Introduction}

Much of the literature on cartel enforcement is theoretical. The empirical papers that exist in Europe focus mainly on enforcement efforts, and draw their conclusions from the information contained in the formal cartel decisions of the European Commission. ${ }^{1}$ The US literature largely focuses on the characteristics of cartels and their effects. ${ }^{2}$ Christine Parker ${ }^{3}$ has conducted an Australian study of $\mathrm{ACCC}^{4}$ enforcement activity and business responses to it, gauging the opinions of enforcement officials, competition lawyers and businessmen. ${ }^{5}$ Finally, Barry Rodger ${ }^{6}$ is conducting surveys on firms that have been fined for involvement in cartel infringements.

Public attitudes are important to cartel policy in four respects. First, individuals' willingness to desist from price-fixing and other collusive behaviour is strongly influenced by how bad they perceive such behaviour to be. The weight of social stigma imposed upon them if caught can have a strong deterrent effect. In as much as the harm caused by cartels is not obvious to people, greater education about the effects of such infringements, and the importance of enforcement, may be necessary to stiffen deterrence. These perceptions will also determine people's willingness to report such behaviour when they think they may be victims of it, or when they suspect their employer to be participating in it.

Second, because cartels are difficult to detect, competition authorities rely heavily on the use of leniency programmes. These typically grant immunity to

\footnotetext{
${ }^{1}$ Examples include: A. Stephan, 'An Empirical Assessment of the 1996 Leniency Notice' (2005) CCP Working Paper 05-10. Presented at the 2006 EARIE conference, Amsterdam. Available at: <http://www.ccp.uea.ac.uk/publicfiles/ workingpapers/CCP05-10.pdf> [all websites accessed 28 May 2007]; Brenner, S. 2005, "An Empirical Study of the European Corporate leniency Program." Presented at the 2005 EARIE conference, Porto. Available at: $<$ http://www.fep.up.pt/conferences/ earie2005/cd rom /Session\%20VII/VII.G/brenner.pdf>; M P Schinkel et al, 'An empirical analysis of Commission Decisions and their Appeals Histories' (2004) Presented at the 2004 EARIE conference, Berlin. Available at: <http://www.diw.de/english/produkte/veranstaltungen/earie2004/papers/docs/ 2004462-V01.pdf.>

${ }^{2}$ Examples include: M Levenstein and V Y Sulsow, 'Contemporary International Cartels and Developing Countries: Economic Effects and Implications for Competition Policy' (2003) Antitrust Law Journal 71:3; J M Connor and R H Lande, 'The size of cartel overcharges: Implications for U.S. and EU fining policies' (2006) The Antitrust Bulletin 51:4, 983; J E Harrington, How Do Cartels Operate? (Now Publishers 2006).

${ }^{3}$ The Melbourne Law School, University of Melbourne

${ }^{4}$ Australian Competition and Consumer Commission

${ }^{5}$ C Parker and N Stepanenko, 'Compliance and Enforcement Project: Preliminary Research Report' (2003) Centre for Competition \& Consumer Policy. Unpublished Paper. Available at: $<$ http://www.cccp.anu.edu.au/Preliminary\%20Research\%20Report.pdf>

$6 \frac{\text { Strathclyde Law School }}{\text { Sth }}$
} 
the first infringing firm that self-reports an infringement and provides evidence of those involved. If cartel infringements are perceived to be too serious, public attitudes may strongly oppose the use of such detection mechanisms as they allow some guilty parties to go unpunished and allow the sanction on others to be substantially reduced.

Third, cartel enforcement in the EU has been dramatically stepped up in the last decade and public support is needed to ensure its success and to back any additional resources required. Leniency programmes have been adopted on the Community level, in the UK and in the majority of other member states. There has also been a significant escalation in the level of fines imposed on infringing firms. In the first quarter of 2007 alone, over $€ 1.6$ billion were imposed in cartel fines by the European Commission. Some national jurisdictions have also adopted criminal offences; notably in the UK where individuals can be imprisoned for up to 5 years for price-fixing under Part 6 of the Enterprise Act 2002. Other enforcement mechanisms are being contemplated, such as the introduction of a system of negotiated settlement. The European Commission also hopes to encourage private enforcement, which is currently perceived as weak in Europe as compared to the US. If the strengthening of cartel enforcement is not in tune with public opinion, many of these enforcement mechanisms may prove ineffective. ${ }^{7}$ Competition authorities may also feel a political backlash if public opinion perceives their enforcement efforts to be too draconian. ${ }^{8}$

Finally, public attitudes give some indication of the willingness to convict individuals at jury trial: in particular, the extent to which price-fixing is considered dishonest for the purposes of the UK criminal offence.

This paper presents an overview of the results of a survey gauging public attitudes in Britain to price-fixing and cartel enforcement mechanisms. This is the first ever survey of consumer attitudes to cartels. A representative sample

\footnotetext{
${ }^{7}$ See for example: C Harding, 'Business Collusion as a Criminological Phenomenon: Exploring the Global Criminalisation of Business Cartels' (2006) 14 Critical Criminology 181 at 197

${ }^{8}$ C Parker, 'The "Compliance" Trap: The Moral Message in Responsive Regulatory Enforcement' (2006) Law \& Society Review 40:3 591
} 
of $1,219^{9}$ residents of Great Britain, aged 18 or over, was surveyed. The survey was carried out between $28^{\text {th }}$ and $30^{\text {th }}$ of March 2007 by YouGov Plc and was commissioned by the ESRC Centre for Competition Policy.

Section 2 of this paper discusses the methodology used in carrying out the survey. Section 3 presents and discusses some of the main survey results.

\section{Methodology}

\subsection{How the survey was carried out ${ }^{10}$}

YouGov Plc maintains a panel of over 160,000 adults throughout Great Britain. In order to register with YouGov, each panel member completes a detailed profiling questionnaire and sets up an account name and password. This questionnaire enables YouGov to select a representative sample each time they conduct a survey - representative according to the demographic make-up of the population. Information acquired at registration includes: region; age; gender; education; housing tender; size of household; children in household; cars in household; daily newspaper readership; vote in last general election; employment status; sector; income; religion; and ethnicity.

The YouGov pool is recruited from a wide variety of sources. Most have been actively recruited via non-political websites. These range from invitations and pop-up advertisements on ISP home pages to websites on varied subjects. YouGov have also employed specialist recruitment agencies to contact specific groups in order to ensure a wide demographic spread.

In conducting the survey, YouGov first selected a sub-group from their pool that was representative of the population as a whole. They then emailed the selected panel members and invited them to complete the survey by clicking

\footnotetext{
${ }^{9}$ As a guide: for a 1,000 sample, margin of error is in the region of $+/-3 \%$ points based on a $95 \%$ confidence interval (YouGov).

10 See YouGov 'Questions \& Answers' available at: <http://www.yougov.com/corporate/aboutQA.asp? $|\mathrm{j} D=1 \& \mathrm{~s}| \mathrm{D}=1 \& \mathrm{UID}>$ and 'How YouGov Works' available at: <http://www.yougov.com/corporate/ aboutYGWorks.asp?jID=1\&sID=1\&UID>
} 
on an Internet link. In order to complete the survey they were required to log in and provide their password. This ensured that the right people completed the survey, and enabled their answers to be matched to the demographics they provided when they registered with YouGov. Respondents receive a small incentive for completing YouGov surveys. The purpose is to ensure that samples are as representative as possible, and that responses are not tilted towards those passionately interested in the subject of the particular survey.

The survey yielded 1,219 responses out of 3,000 members of the public emailed. This is a response rate of about $41 \%{ }^{11}$ When fieldwork was complete, the raw data was adjusted, taking account of age, gender, social class, newspaper readership and past vote (in a general election), to ensure that the results were representative. ${ }^{12}$ Almost all surveys involve weighting, whether they are conducted online, face-to-face or by telephone. This is to ensure that the published results properly reflect the population they seek to measure. $^{13}$

YouGov surveys are also weighted according to past vote and newspaper readership to ensure that results are attitudinally representative as well as demographically representative of the population.

\subsection{Why an online survey?}

For the purposes of statistical analysis probability-based sampling is more desirable than quota sampling. Under the former, the entire population is known and a sample can be selected in such a way that every member of the population has an equal chance of being drawn. This reduces selection errors and produces a sample that is likely to yield more accurate results. If one were surveying employees of a company or some other easily identifiable

\footnotetext{
${ }^{11}$ Typical response rates in telephone surveys can be as low as $15 \%$. See FN 10 and P Kellner, 'Can Online Polls Produce Accurate Findings?' (2004) International Journal of Market Research 46(3)

${ }_{12}$ The combination of sample-selection and weighting techniques currently produces accurate figures for region, employment status and housing tenure, so no further weighting is needed; but, as with potential panel-effects, this data is monitored regularly by YouGov.

${ }^{13}$ For example, men comprise $48 \%$ of the population and women $52 \%$. The raw figures in the survey were close to this ( $49 \%$ and $51 \%$ respectively) but were weighted to reflect the actual population.
} 
population, probability-based sampling could be easily employed. However the difficulty of public surveys is obtaining correspondence information for the population that is complete and accurate. Population censuses are infrequent and many opt out of the publicly available electoral register. Telephone directories are similarly incomplete and an increasing proportion of people now use mobile phones instead of landlines. For these reasons public surveys tend to rely on a quota sample: a group of people is chosen according to their demographic characteristics. They are representative of the general population and so their responses should accurately reflect public attitudes. The difficulty in such surveys is ensuring that no significant group in the population is excluded or under-represented. YouGov's methods for limiting such effects and compensating for them were described in the previous section.

Conventional survey methods include postal self-complete questionnaires, telephone interviews and face-to-face interviews. Postal surveys tend to yield poor response rates mainly due to the volume of 'trash mail' received by households, but also because of the effort required in returning the questionnaire. There is also no way of ensuring that the questionnaire is completed properly or by the right person. Telephone and face-to-face surveys also have difficulty obtaining representative samples. Telephone polling companies generally achieve only 15 interviews for every 100 residential numbers they dial. ${ }^{14}$ There is a difficulty in finding a time that is convenient for all respondents, particularly those who work long hours. Many will refuse to answer questions to strangers over the phone or face-to-face because they consider these to be an infringement of their privacy. Although interviewers in such methods ensure that respondents understand the questions and complete the survey properly, respondents may be less frank in their answers as they may feel rushed or influenced by the interviewer.

Online surveys have the advantage of being anonymous and convenient. People can fill in the survey in private, at a time of their choosing, at their own

\footnotetext{
${ }^{14}$ See YouGov 'Questions \& Answers' (FN 10)
} 
pace, and free from interviewer effects. There is no scope for human error in processing questionnaire data, or reading respondents' handwriting. If an answer has not been selected, the respondent cannot move onto the next question page. Online surveys also prevent respondents from returning to earlier questions at the end of a survey and changing their responses, influenced by the content of later questions.

Online surveys can be criticised for being biased towards the wealthier in society and those more technologically minded. However, internet access has now become affordable, even for low income households. Moreover one would expect the less technologically minded to be older members of the population, yet in the raw (unweighted) data those aged 55 and over were over-represented.

With online surveys there is a danger that respondents randomly select answers without reading the questions in order to complete surveys as quickly as possible. YouGov occasionally asks respondents classification questions they have answered before to check for consistency, and have found little evidence of this. In this survey, respondents were asked more than one question on a number of themes with the choice of answers switched between negative first and positive first. We do not observe conflicting answers between these questions and so are confident that this criticism does not hold. $^{15}$

A Comparison of UK election polls carried out using different research methods since 2001 have shown online polling to be as accurate or better in predicting final election results. ${ }^{16}$ Sanders et $a l^{17}$ look at opinion polls during the 2005 General Election. They find that there are few statistically significant

\footnotetext{
${ }^{15}$ There is also the suggestion that online surveys are biased towards people who use the internet at work for leisure purposes. We asked respondents the extent to which they agreed with the following statement: "Using the internet and telephone at work for leisure purposes is not wrong; most people do it, it is almost a perk of the job". $35 \%$ agreed with this statement, whereas $32 \%$ disagreed. This result may suggest that the bias described above does not exist among respondents of this survey.

${ }^{16}$ See The Economist <http://www.economist.com/media/pdf/YGrecord.pdf>; P Kellner see FN 10; D M Reiner, '2006 EPRG Public Opinion Survey on Energy Security: Policy Preferences and Personal Behaviour' (2006) Judge Business School, University of Cambridge. Unpublished Paper. Available at: <http://www.electricitypolicy.org.uk/pubs/wp/eprg0706.pdf>

${ }_{17}$ D Sanders et al, 'Does Mode Matter for Modelling Political Choice? Evidence From the 2005 British Election Study' (2007) Political Analysis 15 (Autumn)
} 
differences between co-efficients generated through a YouGov internet survey and a conventional face-to-face interview method carried out for General Elections since 1963 by the National Centre for Social Research (Natcen).

\section{The Survey Results}

\subsection{Is price-fixing wrong?}

To ensure balanced and unbiased results, respondents were mainly presented with various scenarios and were asked to either agree or strongly agree with one of two balanced alternatives. They also had the option to agree with neither, or select "don't know". 18

To begin with respondents were asked about their shopping preferences:

Table 1: Willingness to Search

\begin{tabular}{|r|l|}
\hline $\begin{array}{l}\text { SHOPPER A hates shopping around and does not like it } \\
\text { when a friend buys the same item as her cheaper in a } \\
\text { different shop. She likes prices to be identical in all shops. }\end{array}$ & \\
\hline $\begin{array}{l}\text { SHOPPER B enjoys shopping around and does not mind } \\
\text { her friends sometimes getting a better deal. She likes prices } \\
\text { to be different between shops. }\end{array}$ & \\
\hline Are you more like Shopper A or Shopper B? & $\%$ \\
\hline Like Shopper A (of which strongly) & $18(6)$ \\
\hline Like Shopper B (of which strongly) & $66(19)$ \\
\hline Neither Shopper A nor Shopper B & 14 \\
\hline Don't know & 3 \\
\hline
\end{tabular}

Clearly respondents prefer prices to be different between shops and enjoy shopping around, even if they sometimes fail to locate the lowest price.

\footnotetext{
${ }^{18}$ The ordering of the questions was the same for all respondents. The sequence was designed to limit the effect of earlier questions biasing responses to later questions. Except where otherwise stated, questions were asked to all respondents.
} 
Respondents were then asked the first price-fixing question to gauge the extent to which they understand the harmful effects of collusion on price. The term 'fixing prices' was not employed in this first question to test whether it held negative connotations that would bias responses.

Table 2: Price-Fixing I

\begin{tabular}{|c|c|}
\hline $\begin{array}{l}\text { Imagine the owners of } 3 \text { corner shops in your area meet } \\
\text { once a month to agree on what prices to charge for } \\
\text { groceries. }\end{array}$ & \\
\hline $\begin{array}{l}\text { SHOPPER A believes that this is good for their customers } \\
\text { because it ensures similar prices and saves them the hassle } \\
\text { of searching each shop for the lowest price. }\end{array}$ & \\
\hline $\begin{array}{l}\text { SHOPPER B believes that this is bad for their customers } \\
\text { because it will result in much higher prices. }\end{array}$ & \\
\hline Which shopper do you most agree with? & $\%$ \\
\hline Agree with Shopper A (of which strongly) & $17(4)$ \\
\hline Agree with Shopper B (of which strongly) & $69(25)$ \\
\hline Neither Shopper A nor Shopper B & 12 \\
\hline Don't know & 3 \\
\hline
\end{tabular}

The results indicate a strong understanding among respondents that when competitors collude in setting prices, they will look to inflate those prices in order to increase their collective profits, to the detriment of their customers.

However when presented with a situation of market sharing where a wide geographic distribution of competitors yields higher prices, but also convenience, a clear majority of respondents demonstrated a willingness to accept this trade-off. This may indicate that where forms of collusion other than price-fixing bring some benefit to consumers, they are more likely to be acceptable. 
Table 3: Market Sharing \& Convenience

\begin{tabular}{|r|l|}
\hline $\begin{array}{l}\text { At the beginning of summer, the ice cream sellers in a } \\
\text { seaside resort get together and agree where to park their } \\
\text { ice cream vans. This ensures they are well spread out from } \\
\text { one another. }\end{array}$ & \\
\hline $\begin{array}{l}\text { TOURIST A believes that this is bad for their customers } \\
\text { because each ice cream van will charge much higher prices } \\
\text { when situated away from their competitors. }\end{array}$ & \\
\hline $\begin{array}{l}\text { TOURIST B believes this is good for their customers } \\
\text { because they would rather have less distance to walk in } \\
\text { order to buy an ice cream, even if that means paying more. }\end{array}$ & \\
\hline Which tourist do you most agree with? & $\%$ \\
\hline Agree with Tourist A (of which strongly) & $26(9)$ \\
\hline Agree with Tourist B (of which strongly) & $43(9)$ \\
\hline Neither Tourist A nor Tourist B & 27 \\
\hline Don't know & 4 \\
\hline
\end{tabular}

Respondents were then introduced to the term 'fixing prices' and asked whether they believed this to be a harmful practice that should be punished, or a harmless practice that should not. 
Table 4: Price-Fixing II

\begin{tabular}{|l|l|}
\hline $\begin{array}{l}\text { The next scenario is about 'fixing prices'. This is when } \\
\text { competing businesses agree on what prices they will each } \\
\text { charge. }\end{array}$ & \\
\hline & \\
\hline $\begin{array}{l}\text { CITIZEN A believes that 'fixing prices' is a harmless } \\
\text { business practice, that businesses should be free to set } \\
\text { prices how they want and that such practice should not be } \\
\text { punished. }\end{array}$ & \\
\hline $\begin{array}{l}\text { CITIZEN B believes that 'fixing prices' is harmful to } \\
\text { customers, that each business should set its own price } \\
\text { independently, and that such practice should be punished. }\end{array}$ & \\
\hline Which citizen do you most agree with? & $\%$ \\
\hline Agree with Citizen A (of which strongly) & 9 (2) \\
\hline Agree with Citizen B (of which strongly) & $73(37)$ \\
\hline Neither Citizen A nor Citizen B & 14 \\
\hline Don't know & 5 \\
\hline
\end{tabular}

A majority of respondents recognise that price-fixing is harmful and feel it should be punished. The proportion of negative responses to this question is $4 \%$ higher than in the first price-fixing question. This difference may be due to the general nature of this question, as compared to the specific businesses example presented in the first question (corner shops). It may reflect a better understanding of the subject following the introductory questions. Responses may also be affected slightly by the term 'price-fixing'.

Education and newspaper readership appears to have little impact on attitudes towards price-fixing, suggesting that these two mediums are poor at disseminating information about its effects; current cartel laws; and prosecutions in the UK. On the other hand, age seems to have a big impact with only $50 \%$ of $18-24 \mathrm{~s}$ feeling price-fixing is harmful and should be punished, compared to at least $79 \%$ of $45 \mathrm{~s}$ and over (Fig. 5). This suggests that an important source of knowledge about price-fixing may be experience as a consumer. 
Fig. 5: Age

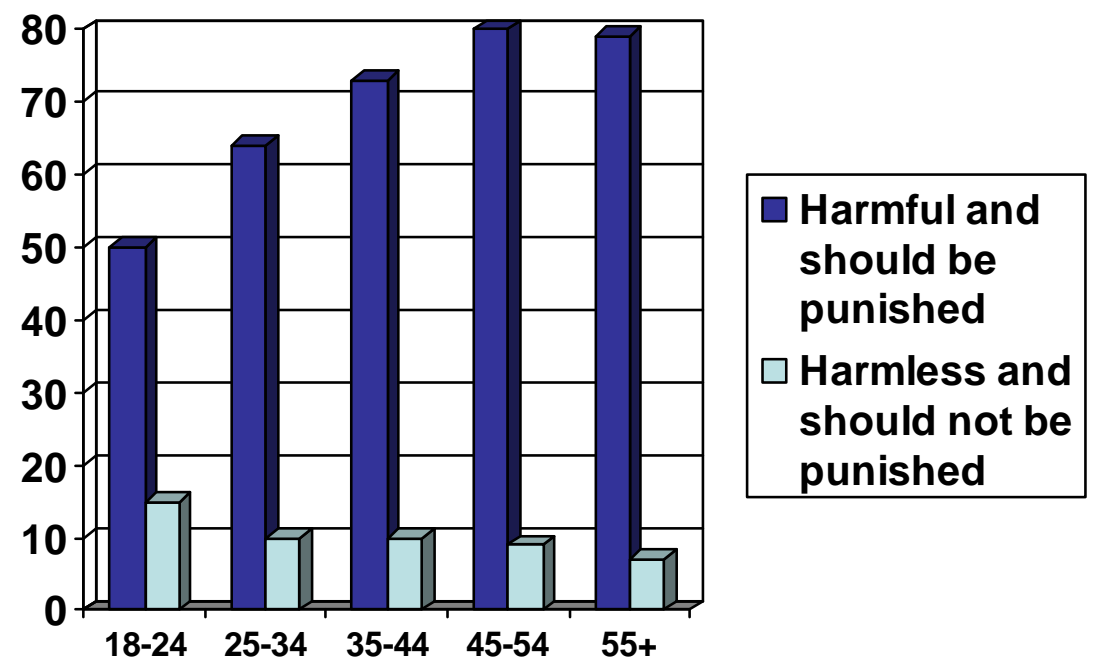

Figures 6-9 illustrate attitudes according to certain demographic characteristics. It is observed throughout the survey that men have more hardened attitudes to price-fixing than women. $80 \%$ of men think it is harmful and should be punished, compared to only $65 \%$ of women (Fig. 6). There is some evidence that attitudes are more hardened in rural areas: for example $82 \%$ in Wales as compared to $67 \%$ in the West Midlands (Fig. 7). This may be because anticompetitive behaviour is more obvious in small towns where there are fewer retailers than in built-up areas. There is a positive relationship between hardened attitudes and wealth, possibly because of greater spending power (Fig. 8). There is also a positive relationship with managerial responsibility (Fig. 9). This is perhaps puzzling given that top level management should have better knowledge about competition law than anyone else within a firm. However it may be that some managers are influenced by the possibility of crisis cartels, which are discussed later in this paper. 
Fig. 6: Sex

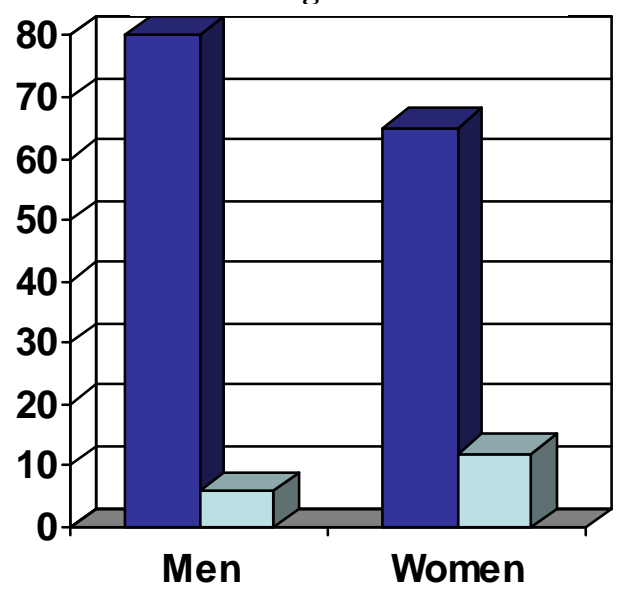

Fig. 8: Social Grade / Wealth

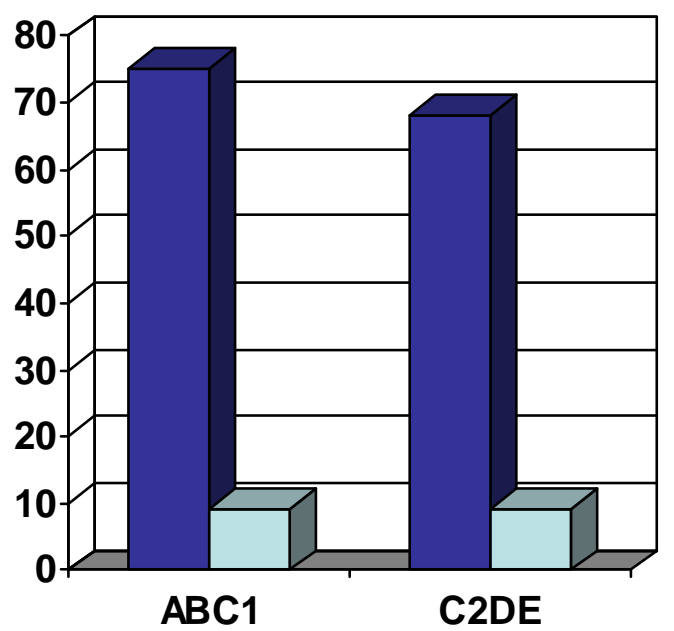

Fig. 7: Region

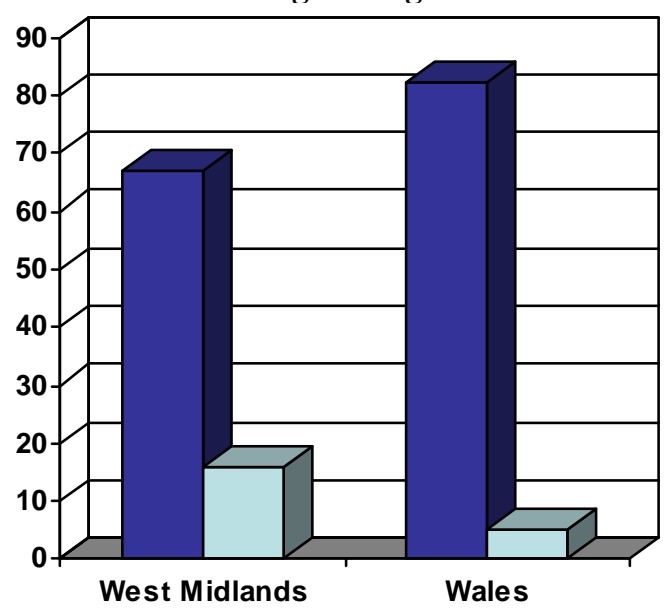

Fig. 9: Managerial Responsibility

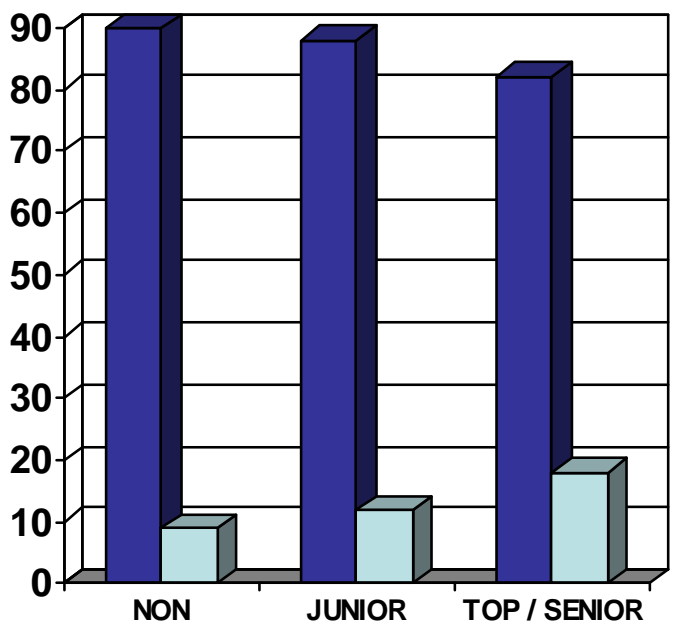

\subsection{Appropriate punishment for firms}

The results in Table 4 confirm strong public support for punishing price-fixing behaviour, but do not tell us how severe the act of price-fixing is perceived to be. At no point in this survey was it revealed to respondents whether pricefixing is illegal in the UK or how it is punishable. All respondents except those who felt price-fixing is harmless (1,110 respondents) were asked a series of questions designed to gauge what they felt is the appropriate punishment for price-fixing. Respondents were presented with a range of punishments which businesses could face for such behaviour and were asked to select which (if any) they felt should apply. 
Table 10: Punishment for Firms *

\begin{tabular}{|c|c|}
\hline $\begin{array}{l}\text { Five large businesses agree to fix prices so that their } \\
\text { customers are charged more than would be the case if they } \\
\text { acted independently, and so that each will earn extra profit... }\end{array}$ & \\
\hline $\begin{array}{l}\text { If each of these BUSINESSES were to be punished, which, if } \\
\text { any, of the following do you think each of these businesses } \\
\text { should face? }\end{array}$ & $\%$ \\
\hline Public Naming and Shaming & 68 \\
\hline Compensation to over-charged customers & 56 \\
\hline Fine equal to the extra profits made & $17^{19}$ \\
\hline Fine greater than the extra profits made & 48 \\
\hline Other & 4 \\
\hline Don't know & 6 \\
\hline None of these/No punishment & 2 \\
\hline
\end{tabular}

The main sanction imposed by competition authorities in the UK and EC is administrative fines. There appears to be substantial public support for imposing fines on price-fixing firms. Interestingly the support is far stronger for fines that exceed the extra profits earned through the cartel, rather than fines proportionate to those profits. A weak majority believe that these firms should be made to compensate affected customers. The sanction with the strongest support is public naming and shaming. Consumers made aware of a firm's anticompetitive behaviour may make efforts to take their business elsewhere. However sanctions aimed at affecting a firm's reputation faces two problems. First, most cartels prosecuted by the European Commission in the last decade concern upstream markets where the immediate victims of price-fixing are other firms purchasing goods. These firms may simply pass on the higher prices to final consumers. Second, the very characteristics that make pricefixing possible (few firms in the industry, barriers to entry, low substitutability of the good produced) also mean that buyers have little choice but to continue

\footnotetext{
${ }^{19}$ The results have been adjusted so that those respondents who selected both "fine equal to" and "fine greater than" the extra profits made, are classed as having selected only the latter.
} 
purchasing from these firms post-collusion, regardless of how low their opinion of them becomes.

\subsection{Appropriate punishment for individuals}

Table 11: Punishment for individuals*

\begin{tabular}{|c|c|}
\hline $\begin{array}{l}\text { The decision to fix prices is usually made by a number of } \\
\text { INDIVIDUALS within a business... }\end{array}$ & \\
\hline $\begin{array}{l}\text { In addition to the punishment (if any) you stated businesses } \\
\text { should receive, if each of the INDIVIDUALS in a business } \\
\text { were to be punished, which, if any, of the following do you } \\
\text { think each of these individuals should face? }\end{array}$ & $\%$ \\
\hline Public Naming and Shaming & 55 \\
\hline $\begin{array}{r}\text { A ban from holding senior managerial positions in } \\
\text { businesses }\end{array}$ & 48 \\
\hline A personal fine & 42 \\
\hline Imprisonment & 11 \\
\hline Other & 2 \\
\hline Don't know & 9 \\
\hline None of these/No punishment & 5 \\
\hline
\end{tabular}

The vast majority of respondents who felt firms should be punished for pricefixing behaviour also felt that the individuals responsible within those businesses should be punished. Bans from holding senior managerial positions and personal fines both have significant public support. The most popular sanction again proved to be public naming and shaming. Table 12 indicates that it is generally the same people who believe that firms and individuals should face public naming and shaming, rather than just one or the other. 
Table 12: Public Naming \& Shaming Comparison

\begin{tabular}{|c|c|c|c|}
\hline $\begin{array}{c}\text { Public Naming \& } \\
\text { Shaming }\end{array}$ & \multicolumn{3}{|c|}{ Individuals } \\
\hline \multirow{3}{*}{ Firms } & & YES & NO \\
\cline { 2 - 4 } & YES & $50 \%$ & $18 \%$ \\
\cline { 2 - 4 } & NO & $5 \%$ & $27 \%$ \\
\hline
\end{tabular}

It is unclear what effect, if any, the public naming and shaming of individuals has. Many of these individuals may otherwise be considered 'decent' members of their community. ${ }^{20}$ If their actions are known within their industries, and firms worry about reputation, then these individuals may find it difficult to seek employment.

The results in tables 10 and 11 may reflect how the perceived personality behind the wrongdoing will always be first and foremost the firm, rather than the individual. A significant divergence of opinion between men and women is again observed:

Fig. 13: Sex
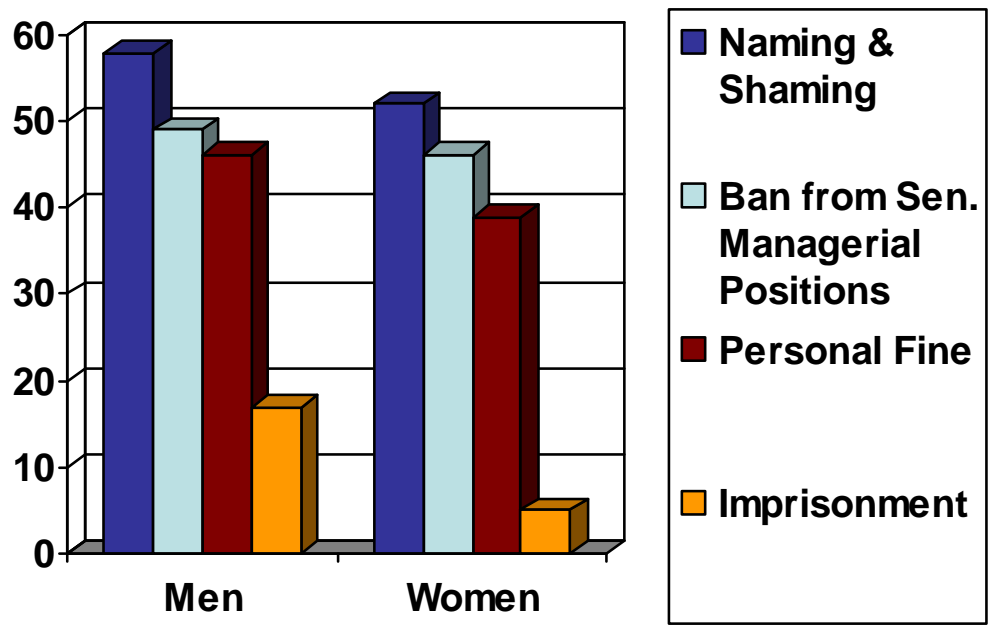

\footnotetext{
${ }^{20}$ See for example character references presented in mitigation for $\mathrm{J} P$ Lambe following his guilty plea in the Irish Heating Oil Case: The Irish Independent ' $€ 4.4 \mathrm{~m}$ fuel price-fixer gets a €15,000 fine' 07 Mar 2006 available at: <http://www.independent.ie/national-news/44m-fuel-pricefixer-gets-a-15000-fine-106337.html>
} 


\subsection{Significance for the UK criminal cartel offence}

The results in Table 11 have strong implications for the criminal offence set out in Part 6 of the Enterprise Act 2002. By virtue of s.190, convicted individuals could face imprisonment of up to five years. The results are also interesting in light of the lan Norris case. The US is trying to secure the extradition from Britain of the former chairman of Morgan Crucible for pricefixing in violation of the Sherman Act. Because the offence in question preceded the introduction of the UK criminal offence (and thus was not a crime in the UK at the time), prosecutors arguing on behalf of the US are relying on the common law crime of conspiracy to defraud. This has never been applied to price-fixing before, but the extradition proceedings have thus far been successful. ${ }^{21}$ At the time of writing, Norris had won the right for his appeal to be heard in the House of Lords. ${ }^{22}$ The US is likely to continue seeking the extradition of British nationals on price-fixing charges, for example in the current British Airways case. ${ }^{23}$

The survey reveals very weak public support for the imprisonment of individuals who have committed price-fixing, with only 1 in 10 people (11\%) feeling it is appropriate. There is an interesting divergence here in responses between men and women. $17 \%$ of men support the imprisonment of individuals, compared to a mere $5 \%$ of women.

The UK criminal offence employs the dishonesty test from $R \vee$ Ghosh. ${ }^{24}$ In order for an individual to be convicted, a jury must determine that:

1. ... according to the ordinary standards of reasonable and honest people what was done was dishonest. [If it was not dishonest, the test is not satisfied]

2. [and] ...the defendant himself must have realised that what he was doing was by those standards dishonest. (recital 696)

\footnotetext{
${ }^{21}$ See J. Joshua, 'The European Cartel Enforcement Regime Post-Modernisation: How is it working?' (2006) Geo. Mason Law Review. Vol 13:6 1248, 1269

${ }^{22}$ e.g. M Herman 'Norris cleared to take extradition fight to Lords' The Times (London, 13 March 2007) available at: $<$ http://business.timesonline.co.uk/tol/business/law/corporate/article1508737.ece>

${ }^{23}$ D Leppard "BA chiefs face extradition over "price fixing" The Sunday Times (London, 27 May 2007) available at: <http://www.timesonline.co.uk/tol/news/uk/crime/article1845234.ece>

${ }^{24}[1982] 2$ ALL ER 689
} 
As yet no one has been convicted of the UK criminal offence. No doubt in attempting to convince a jury that the dishonesty test has been satisfied, the Office of Fair Trading (OFT) or the Serious Fraud Office (SFO) may produce evidence that the individual tried to hide cartel meetings, or that they knew such behaviour was illegal. However the jury will enter the court with preconceptions about the act of price-fixing and its severity. Mindful of this, we included a dishonesty question in the survey. All respondents were asked whether they felt price-fixing is dishonest:

Table 14: Dishonesty

\begin{tabular}{|r|l|}
\hline & $\%$ \\
\hline Dishonest (of which strongly) & $63(25)$ \\
\hline Not Dishonest (of which strongly) & $21(2)$ \\
\hline Neither & 11 \\
\hline Don't know & 5 \\
\hline
\end{tabular}

Approximately 6 in every 10 Britons (63\%) believe price-fixing is dishonest, whereas two in every ten (21\%) believe it is not dishonest. This figure is lower than one would expect given that the overwhelming majority of respondents do recognise that price-fixing is wrong (Table 4). Figures 15 and 16 confirm effects of age and sex identified earlier in this paper.

Fig. 15: Age

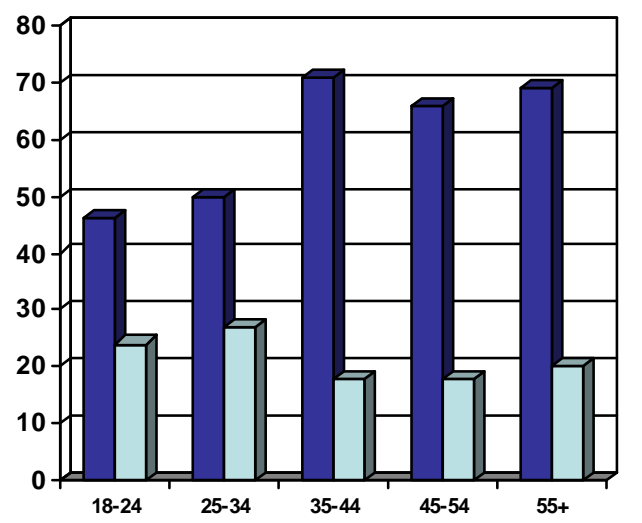

Fig. 16: Sex

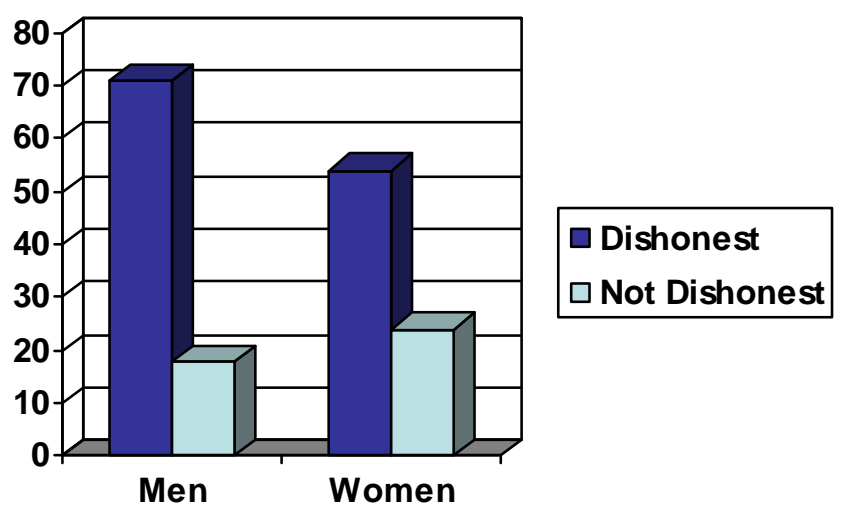


The results may reflect insufficient knowledge about the nature of price-fixing, its harmful effects and the laws which ban such behaviour. This lack of knowledge should be remedied in the course of a trial. However, it may also be that the dishonesty test is not well suited to the cartel offence. Its origins are in cases concerning theft, the effects and nature of which are a lot clearer to people. By contrast individuals may pay a cartel inflated price for a product but still objectively feel that price was fair.

We asked respondents the following open question, meaning that they could enter any answer they wished.

Table 17: Equivalence

\begin{tabular}{|r|l|}
\hline $\begin{array}{l}\text { What other practice and/or behaviour do you think 'fixing } \\
\text { prices' is comparable to }- \text { in terms of how GOOD or BAD you } \\
\text { consider it to be? }{ }^{25}\end{array}$ & $\%$ \\
\hline Don't Know & $65^{26}$ \\
\hline Fraud & 8 \\
\hline Theft & 7 \\
\hline Other $^{27}$ & 20 \\
\hline
\end{tabular}

Only $7 \%$ of respondents felt that price-fixing is comparable to theft. $8 \%$ felt it was comparable to fraud. A strong majority clearly had trouble relating it to any other illegal act with which they were familiar.

\footnotetext{
${ }^{25}$ The responses to this question have been classified manually by Stephan (not YouGov) and so there may be some human error

${ }^{26}$ This does not include blank answers. Respondents chose to enter DK

${ }^{27}$ All other responses including a small number of incoherent inputs
} 


\subsection{When price-fixing should be punished}

Table 18: When Punishment should occur ${ }^{*}$

\begin{tabular}{|c|c|}
\hline $\begin{array}{l}\text { WHEN do you think businesses and individuals should be } \\
\text { punished for agreeing to fix prices? }\end{array}$ & $\%$ \\
\hline $\begin{array}{r}\text { Whenever price-fixing has occurred, even if prices have } \\
\text { not gone up }\end{array}$ & 56 \\
\hline Only if prices have gone up & 24 \\
\hline Only if prices have gone up by at least a fifth & 6 \\
\hline Other & 2 \\
\hline Don't know & 11 \\
\hline None of these & 2 \\
\hline
\end{tabular}

A majority of those who support punishment believe it should be imposed whenever price-fixing has occurred, even if prices have not gone up. Many cartels occur as a result of crisis in an industry and only succeed in reducing the speed with which prices are falling, rather than achieving a price increase. ${ }^{28}$ For the purposes of deterrence it is also important that all such agreements are punished regardless of whether they are implemented or effective. $^{29}$

However some economists, most notably Richard Posner, ${ }^{30}$ contend that cartels should only be punished if they succeed in raising prices. Rather than imposing punishments only on cartel infringements that have an effect, competition law generally focuses on the intention to fix prices, regardless of whether this actually has an impact on prices. It is for this reason that tacit collusion ${ }^{31}$ cannot be punished. ${ }^{32}$ Posner argues that while competition

\footnotetext{
${ }^{28}$ See Stephan (FN 1)

${ }^{29}$ See M Motta Competition Policy (Cambridge University Press 2004) 185-190

${ }^{30}$ R A Posner, Antitrust Law $2^{\text {nd }}$ Ed. (University of Chicago Press 2001), Chapter 3

${ }^{31}$ Where prices increase as a result of collusion between competitors, without an explicit agreement existing between them. This is usually observed in oligopolistic markets where there are few competitors. 'Tacit collusion' can also be described as 'coordinated effects' and 'conscious parallelism'.

${ }^{32}$ The European Commission famously had a decision in such a case annulled by the European Court of Justice. In Wood Pulp (A Ahlström Oy v Commission [1993] 4 CMLR 407), the Commission argued that price announcements (purportedly used as a signalling tool) constituted an infringement of Article 81. The case showed that alleged collusive behaviour, short of an explicit agreement, can easily be doubted using different economic arguments. These can usually explain the observed behaviour as something other than tacit collusion. The Commission is unlikely to attempt such a case again as it would need to anticipate and rebut all such possible arguments at appeal.
} 
authorities' limited resources are being employed to punish failed cartels, more serious successful price-fixing goes unpunished and undetected because overt communication must be proved. He suggests that an effects based economic approach should be employed instead. ${ }^{33}$

\subsection{Exceptions to price-fixing laws}

Many cartels are formed as a reaction to crises in an industry, such as long term decline, or new competition from another part of the world. ${ }^{34}$ It can be argued that such collusive agreements have the protection of employment as one of their aims. There is a question of whether cartels conceived with such motivations should be treated any differently to cartels formed purely out of greed. A firm's ability to pay is taken into consideration as a mitigating circumstance when the European Commission calculates fines. ${ }^{35}$ If such firms are undergoing financial difficulties there are strong implications for loss of employment within the Community. Arguments of virtuous intentions by cartelists could also jeopardise a conviction under the criminal offence. ${ }^{36}$

We asked respondents who felt price-fixing should be punished whether there should be any exceptional circumstances. This was an open question; respondents were free to enter any answer they wished.

\footnotetext{
${ }^{33}$ See Posner (FN 30) 69-93

${ }^{34}$ See Stephan (FN 1)

${ }^{35}$ A Stephan, 'The Bankruptcy Wildcard in Cartel Cases' (2006) Journal of Business Law, August Issue, 511-534

${ }^{36}$ A MacCulloch, 'Honesty, Morality and the Cartel Offence' (2007) E.C.L.R. 2007, 28(6), 355-363
} 
Table 19: Situations Where there Should be No Punishment ${ }^{\star}$

\begin{tabular}{|c|c|}
\hline $\begin{array}{l}\text { Can you think of a situation where you feel fixing } \\
\text { prices should NOT be punished? } ?^{37}\end{array}$ & $\%$ \\
\hline None & 49 \\
\hline Don't Know & 34 \\
\hline Where it benefits consumers / Lowers prices & 8 \\
\hline Where it protects employment or small businesses & 2 \\
\hline Other $^{38}$ & 7 \\
\hline
\end{tabular}

The results show limited support for justifications on the basis of benefits to consumers in the style of Article 81(3) exemptions. A third of respondents were uncertain.

Later in the survey, we asked all respondents whether factories that formed a cartel to avoid closing down in an area with high unemployment should be exempt from price-fixing laws.

\footnotetext{
${ }^{37}$ The responses to this question have been classified manually by Stephan (not YouGov) and so there may be some human error. Respondents were instructed: 'If there is no situation, please type in 'NONE' or if you don't know, please type in 'DK".

${ }^{38}$ All other responses including a small number of incoherent inputs
} 
Table 20: Crisis Cartels \& Protecting Employment

\begin{tabular}{|l|l|}
\hline $\begin{array}{l}\text { In a country where price-fixing is illegal, three factories are } \\
\text { the main employers in a poor region where unemployment } \\
\text { is high. In order to avoid closing down, the factory owners } \\
\text { agree to fix prices at a higher level than would otherwise be } \\
\text { the case. }\end{array}$ & \\
\hline $\begin{array}{l}\text { POLITICIAN A believes that these factories should be } \\
\text { exempt from price-fixing laws in order to protect jobs in this } \\
\text { poor region. }\end{array}$ & \\
\hline $\begin{array}{l}\text { POLITICIAN B believes these factories should face the } \\
\text { same consequences as any other business that breaks the } \\
\text { law. }\end{array}$ & \\
\hline Which politician do you most agree with? & $\%$ \\
\hline Agree with Politician A (of which strongly) & $23(4)$ \\
\hline Agree with Politician B (of which strongly) & $49(8)$ \\
\hline Neither Politician A nor Politician B & 17 \\
\hline Don't know & 11 \\
\hline
\end{tabular}

The proportion of respondents against an exemption remained the same. Presented with a specific scenario, around $20 \%$ of those unsure in the open question above supported an exemption. Support for protecting employment in this situation is significant; but perhaps a lot lower than one would expect. These results may signal respondents' greater acceptance of job mobility and declining sympathy towards failing companies. ${ }^{39}$ It is reasonable to speculate that public opinion in other EU countries such as France may be far more sympathetic to concerns over loss of employment. The effects of age and sex are consistent with earlier results presented in this paper. Education, managerial responsibility and newspaper readership have less significance.

One might think that public support for price-fixing laws only extends to large scale infringements or those committed by industries enjoying substantial profit. To test this, all respondents were asked whether price-fixing should be banned for various businesses:

\footnotetext{
${ }^{39}$ For example, this was reflected in the surprisingly subdued public reaction to the downfall of MG-Rover in 2005; See generally: $B B C$ News 'MG Rover Collapse' available at: <http://news.bbc.co.uk/1/hi/in depth/business/2005/mg rover/default.stm>
} 
Fig. 21: Different size/types of Businesses

'Fixing Prices' can be used by firms as a way of increasing their profits. Do you think a law banning such practice should apply to any of the following...?

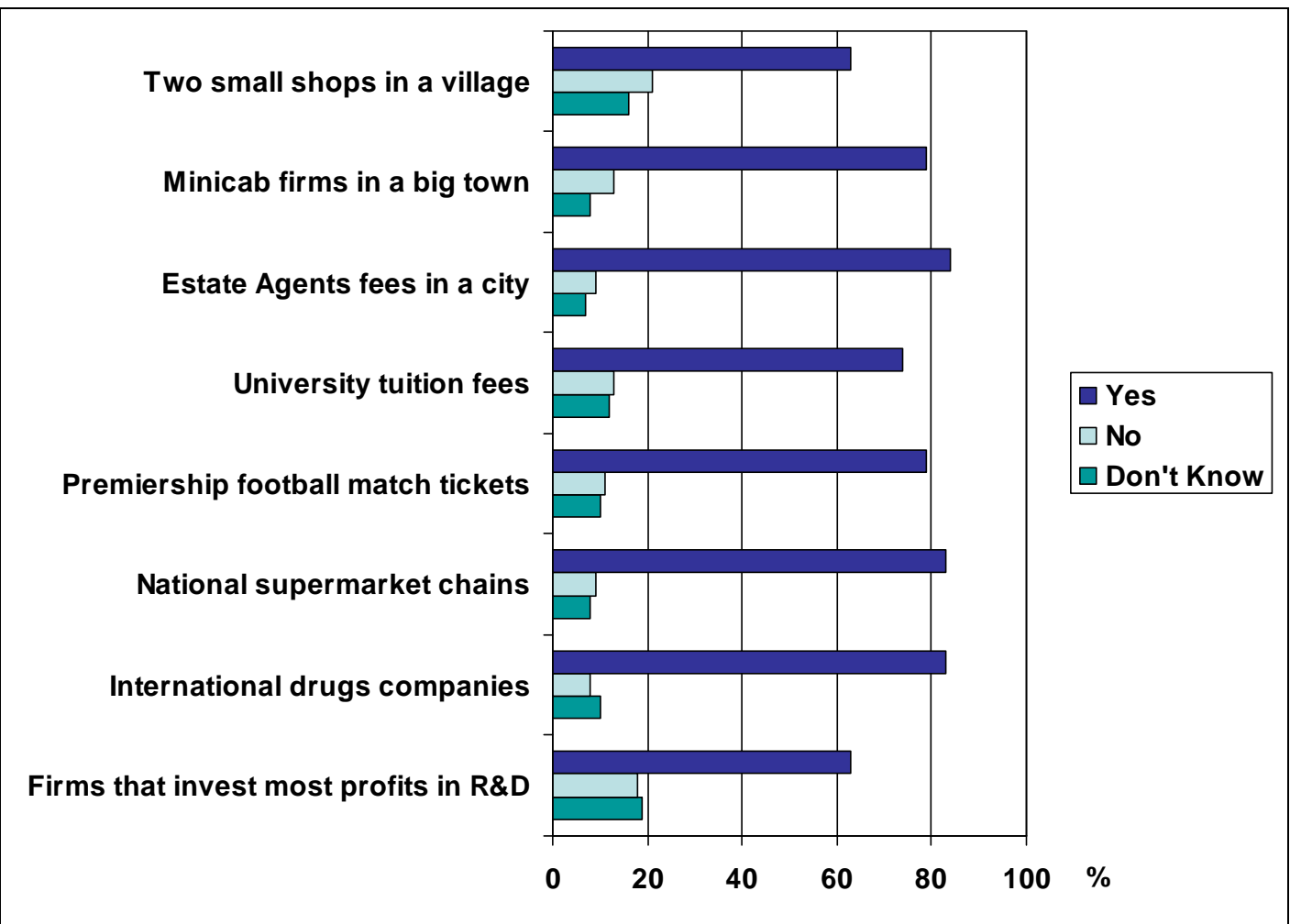

Support for an exemption to punishing price-fixing is weak even for two small shops in a village or firms that invest most of their profits in research and development. Respondents are particularly unforgiving when it comes to Pharmaceutical companies, Estate Agents and Supermarkets.

The results presented in this section should give competition authorities greater courage in imposing fines on firms that accurately reflect the infringement they have committed, and should not be sidetracked by concerns over employment or the nature of the infringing business. In Britain at least, the public largely feel that firms should face the same consequences, regardless of the motivation behind price-fixing or their circumstances. 


\subsection{Attitudes towards leniency programmes}

Cartel agreements are secretive in nature and pursuing them through investigations alone is a very costly and ineffective method. Competition authorities have come to strongly rely on leniency programmes. These typically provide immunity from fines to the first firm to self-report an infringement to the authority and disclose information about the other participants. The European Commission first adopted its leniency programme in 1996. It was reformed in 2002 and again in $2006 .{ }^{40}$ The UK adopted a leniency programme under the Competition Act $1998 .^{41}$

All respondents were asked whether granting immunity in order to prosecute a cartel that would not otherwise have been detected is justifiable:

Table 22: Immunity under a Leniency Programme

\begin{tabular}{|r|l|}
\hline $\begin{array}{l}\text { Five large businesses agree to fix prices in a country where } \\
\text { this is illegal. The manager of one of these businesses } \\
\text { reports the agreement to the authorities in return for a } \\
\text { guarantee that they and their business will not be punished. } \\
\text { The four other businesses are fined heavily. All five were } \\
\text { equally guilty, but none would have been punished had the } \\
\text { manager not come forward. }\end{array}$ & \\
\hline $\begin{array}{r}\text { To what extent do you agree or disagree that it was RIGHT } \\
\text { for the authorities to give a guarantee against punishment to } \\
\text { one guilty business in order to catch the other four? }\end{array}$ & $\%$ \\
\hline Agree (of which strongly) & $\mathbf{3 7}(6)$ \\
\hline Disagree (of which strongly) & 38 (12) \\
\hline Neither agree nor disagree & 17 \\
\hline Don't know & 8 \\
\hline
\end{tabular}

The survey reveals weak but significant support for leniency programmes. For many there is something unsavoury about allowing a guilty party to walk away free. The greater the punishment faced by those firms beaten to the immunity

\footnotetext{
40 'Commission Notice on Immunity from fines and reduction of fines in cartel cases' OJ C298 8.12.2006

41 See 'OFT's Guidance as to the appropriate amount of a penalty' 2004 available at <http://www.oft.gov.uk/shared oft/business leaflets/ca98 guidelines/oft423.pdf>; and 'Leniency in cartel cases' available at <http://www.oft.gov.uk/shared oft/business leaflets/ca98 mini guides/ oft436.pdf $>$
} 
'prize', the more unsavoury it becomes. However it is this stark difference that also makes leniency programmes effective in uncovering infringements.

In this respect, competition authorities may be faced with a challenge. They are trying to strengthen people's perception of how bad price-fixing is by using highly emotive and moral language. ${ }^{42}$ However, as people's perception of cartels hardens, public support for leniency programmes is likely to weaken further. The worse they are perceived to be, the more objectionable letting one go unpunished becomes. Yet such programmes lie at the heart of effective cartel enforcement mechanisms. It may even be that their presence will act as an obstruction to strengthening negative perceptions of cartels. The message sent out may be: if some price-fixers are given immunity then it surely cannot be as bad as theft or fraud!

\subsection{Willingness to report price-fixing behaviour}

Apart from leniency programmes, competition authorities also rely on complaints to better direct their investigations into cartel agreements. The most obvious source of complaints is the customers of colluding firms, be they final consumers or other businesses. However many cartels are aware of this danger and conduct their collusive behaviour with caution. Prices may rise over long periods of time, justified by purported increases in cost or demand. Cartels may also choose to raise prices, not through price-fixing, but instead through market sharing and output restriction.

The individuals best placed to report cartel behaviour may be the employees of the colluding firms. In the US, the Department of Justice will sometimes enter into plea bargains with individuals involved in collusion, pitting them against their employer in obtaining cooperation. There may also be great potential for the reporting of infringements by individuals not directly involved in price-fixing, but who are aware that it is occurring within their firm. One would expect compliance programmes to have mechanisms in place which

\footnotetext{
${ }^{42}$ See discussion in Harding (FN 7) at 183
} 
can be utilised by such individuals. However many firms do not have competition law compliance programmes in place, and there may be reluctance to come forward for fear of adverse consequences internally. We tested respondents' willingness to report their employer's anticompetitive behaviour:

Table 23: Willingness to Report Employer

\begin{tabular}{|l|l|}
\hline $\begin{array}{l}\text { Six people work for a large business they know to be involved } \\
\text { in fixing prices in a country where this is illegal. Each } \\
\text { considers whether to report their employer's illegal practice to } \\
\text { the authorities. Which employee is most likely to reflect your } \\
\text { own actions in this situation? }\end{array}$ & \% \\
\hline $\begin{array}{l}\text { EMPLOYEE A will not report it because they believe } \\
\text { price-fixing should not be illegal. }\end{array}$ & 2 \\
\hline $\begin{array}{l}\text { EMPLOYEE B immediately reports this practice because } \\
\text { it is illegal. }\end{array}$ & 20 \\
\hline $\begin{array}{l}\text { EMPLOYEE C will report it only if they can remain } \\
\text { anonymous. }\end{array}$ & 49 \\
\hline $\begin{array}{l}\text { EMPLOYEE D will report it only if they can remain } \\
\text { anonymous and are given a reward equivalent to a } \\
\text { month's wages. }\end{array}$ & 2 \\
\hline $\begin{array}{l}\text { EMPLOYEE E will report it only if they can remain } \\
\text { anonymous and are given a reward equivalent to a year's } \\
\text { wages. }\end{array}$ & 4 \\
\hline $\begin{array}{l}\text { EMPLOYEE F will not report it because they fear there is } \\
\text { too much at stake; they worry they may lose their job. }\end{array}$ & 14 \\
\hline \multicolumn{1}{|c|}{ None of them't know } & 2 \\
\hline & 7 \\
\hline
\end{tabular}

These results reveal that the majority of respondents would only consider reporting price-fixing if they (at the very least) could be guaranteed anonymity. A significant proportion would not report an infringement, fearing the consequences even where an offer of anonymity and a reward of a year's wages is available. The proportion of people unwilling to report even in return for a reward may very well be under-represented in this survey. When asked if they would hypothetically report a breach of the law, it is easier for respondents to answer yes. A survey question cannot capture the emotional pressures and potential consequences that would exist in such a situation, 
many of which are unforeseeable. The responses above suggest that competition authorities should have clear mechanisms in place guaranteeing anonymity to potential whistleblowers within a colluding firm.

\subsection{Attitudes towards private enforcement}

The European Commission and OFT are making efforts to encourage private actions for damages in cartel cases. These can take the form of original actions in cases where an infringement has not been prosecuted by a competition authority. More commonly they take the form of follow-on suits subsequent to the finding of an infringement through public enforcement. ${ }^{43}$ Respondents were asked whether they felt compensating customers who have been over-charged by price-fixing is more important than imposing deterrent sanctions on infringing firms:

Table 24: Compensation*

\begin{tabular}{|r|l|}
\hline Which of these do you consider to be MORE important? & $\%$ \\
\hline $\begin{array}{r}\text { Making sure businesses compensate the customers who } \\
\text { have paid higher prices as a result of their price-fixing }\end{array}$ & 14 \\
\hline $\begin{array}{r}\text { Imposing a punishment on those businesses that is high } \\
\text { enough to make others think twice before fixing prices in } \\
\text { the future }\end{array}$ & 38 \\
\hline Both are equally important & 42 \\
\hline Don't know & 4 \\
\hline $\begin{array}{r}\text { * Those who agreed with Citizen B (who believed that 'fixing prices' is harmful to } \\
\text { customers) or were undecided/ did not know }\end{array}$ & 2 \\
\hline
\end{tabular}

Respondents placed greater importance on the imposition of punishment by a competition authority than on ensuring those 'injured' by price-fixing are compensated. The results in this question are consistent with that in Table 10

\footnotetext{
${ }^{43}$ See the Commission's Green Paper 'Actions for damages' (Dec 2005) available at: <http://europa.eu.int/comm/competition/antitrust/others/actions for damages/index en.html>; see also OFT Discussion Paper 'Private actions in competition law: effective redress for consumers and business' (April 2007), available at: <http://www.oft.gov.uk/shared oft/reports/comp policy/ oft916.pdf>
} 
where $56 \%$ of those supporting punishment believed that firms should be made to compensate over-charged customers. Some may simply not consider price-fixing to be serious enough to warrant payments of compensation. Others may recognise how the effects of price-fixing can be dispersed, with the extra cost only representing a small proportion of a final consumer's income. The results may also suggest that people expect the competition authority to compel firms into compensating their customers, rather than expecting buyers to embark on the risky and potentially expensive option of suing for damages.

\section{Concluding Remarks}

The survey indicates that the majority of Britons (73\%) recognise the harmful effects of price-fixing. They understand that colluding competitors will set prices so as to maximise their collective profits to the detriment of their customers. They also recognise the need for such behaviour to be punished, and do not feel that crisis cartels for the protection of employment or small businesses should be exempt. There is a stark divergence throughout the survey between the attitudes of men and women, the former being far less sympathetic towards price-fixing.

However, while there is strong support for significant fines to be imposed on infringing firms, only $11 \%$ feel the imprisonment of individuals is appropriate. The dishonesty test in the UK criminal offence is borrowed from criminal law, yet only $7 \%$ of respondents would compare price-fixing to theft, and only $8 \%$ to fraud. Most fail to draw obvious parallels between price-fixing and conventional crimes. Moreover only 6 in every 10 people think price-fixing is dishonest; suggesting that, while a social stigma against such behaviour exists, it is not strong enough to support imprisonment. This may make it hard to secure a conviction under the UK criminal offence. The sanction most favoured by respondents is the naming and shaming of both price-fixing firms and individuals. 
These results may reflect a lack of information and public knowledge about the nature of price-fixing; the extent of the harm that it can cause; and the laws and sanctions which are currently in place to tackle it. The fact that education and newspaper readership have little effect on how hardened people's attitudes are to price-fixing suggests that little information is available through these two mediums. By contrast, the fact that attitudes towards pricefixing harden with age suggests that people's understanding of its harmful effects is derived largely through their experience as consumers. More should be done to increase public awareness about the effects of price-fixing, current cartel laws, and prosecutions. The American Antitrust Institute has produced an educational video called 'Fair Fight in the Market Place', ${ }^{44}$ which is about price-fixing, and is specifically targeted to a high school audience. Schools and local TV stations throughout the US are being encouraged to show the film.

Public opinion is divided as to whether the use of immunity in leniency programmes is justifiable. With better education and information about the nature of price-fixing, the public may warm to the use of the criminal offence. However there may be an inherent tension when it comes to leniency: the more severe people perceive the crime of price-fixing to be, the more unsavoury the prospect of granting immunity to an infringing firm may become.

Should they become aware that their employer is involved in price-fixing, most respondents show great reluctance to report the infringement per se. $14 \%$ of respondents would not report the infringement even in return for a reward equivalent to a years wages. Competition authorities need to provide clear mechanisms guaranteeing anonymity to whistle-blowing employees as nearly half of respondents would only report if they could rely on such a guarantee.

In relation to private enforcement, respondents generally consider public enforcement to be more important than ensuring compensation is paid to

\footnotetext{
${ }^{44}$ See 'AAI Film FAIR FIGHT IN THE MARKET PLACE is Going National': $<$ http://www.antitrustinstitute.org/Archives/fff.ashX>
} 
'injured' customers. Indeed, the responses can be read to indicate that people expect the competition authority to impose compensation as a sanction on infringing firms, rather than seeking damages through the courts. This may go some way towards explaining why private enforcement in the UK appears to be weak in comparison to certain other jurisdictions.

This paper has given an overview of the survey results pending more detailed analysis. This is likely to concentrate on the demographic characteristics of those more hardened to price-fixing and more accepting of enforcement mechanisms; further implications for the UK criminal cartel offence; and a more detailed look at the significance for private enforcement in cartel cases. Plans for future research include the prospect of carrying out a similar survey in a different EU member state to observe what difference culture, among other factors, has on attitudes to price-fixing and cartel policy. 